\title{
BIOCHEMICAL AND IMMUNOLOGICAL STUDIES ON PURINE NUCLEOSIDE PHOSPHORYLASE ISOLATED FROM COW SNOUT EPIDERMIS
}

\author{
MASANORI KINOSHITA \\ Department of Medical Biochemistry, Kurume University \\ School of Medicine, Kurume, 830, Japan
}

(Received for publication October 8, 1977)

\begin{abstract}
Purine nucleoside phosphrylase (purine nucleoside: orthophospate ribosyl transferase PNPase, EC 2. 4. 2. 1) was purified 237-fold in a specific activity from cow snout epidermis. Inosine was highly utilized as substrate among the purine nucleosides tested. The molecular weight of the enzyme was estimated at about 80,000 by the use of Sephadex G-200 gelfiltration. The Michaelis constant for inosine was $0.04 \mathrm{mM}$.

There was no immunological cross-reactivity between antiserum of cow snout epidermal PNPase and calf spleen PNPase or extracts of cow liver, intestinal epitherium, kidney.
\end{abstract}

\section{INTRODUCTION}

One of the physiological functions of the epidermis is a production of the horny layer. Histologically, no cellular constituents including nuclei are present in the horny layer. During normal keratinization, nucleoproteins are first broken down to DNA and RNA. Futher catabolism of nucleic acids probably proceeds along the same pathways as in other mammalian tissues. The endogenous levels of DNA are to be under the control of both synthetic and catabolic enzymes in the epidermis. DNAnucleolytic enzymes which effect this degradation may be of great significance in the overall biological control processes in the epidermis. Since work from our laboratory has shown that the DNA-nucleolytic enzymes are purified from cow snout epidermis, their biological characteristics in the cellular differentiation have been discussed. During past studies (Miyagawa and Ogura, 1971 ; Hidaka, 1976). It became apparent that there were a number of enzymes present in the epidermis which were capable of degrading DNA into nucleoside.

However, biochemical characteristics of purine nucleoside phosphorylase in the epidermis remain to be examined using a homogenous enzyme preparation.

The present work describes purification and characterization of purine nucleoside phosphorylase (PNPase) in

Abbreviation used

PNPase : purine nucleoside phosphorylase 
cow snout epidermis.

\section{MATERIALS AND METHODS}

\section{Materials}

Cow snout epidermis was used as a source of PNPase preparation. The cow snout was obtained in the slaughter house. Crystalline PNPase from calf spleen and xanthine oxidase were purchased from Boehringer Mannheim. Inosine, adenosine, hypoxanthine, uric acid were obtained from Wako Co. Ltd. All other chemicals were of the highest purity commercially available.

\section{Preparation of crude extracts}

The skin was excised from cow snout and the subcutaneous tissue was removed. The epidermis was sliced by a laboratory cryostat-microtome (Yamatokoki, Japan Model 1118) with the cutting blade adjusted to 10 micron thickness. The slices obtained from whole epidermis were pooled, and homogenized in 10 vol. of distilled water with a glass homogenizer, and centrifuged at 20,000 $\times \mathrm{g}$ for $15 \mathrm{~min}$; the supernatant fluid was used for enzyme assays, as an epidermal homogenate in this paper.

\section{Assay of purine nucleoside phos- phorylase}

Assay utilized in this paper is the coupled xanthine oxidase method of Kalckar (1947), which is based on the measurement of the increase in absorbance at $292 \mathrm{~nm}$ due to the formation of uric acid.

The optical absorption at $292 \mathrm{~nm}$ of reaction mixture was determined with a Beckman model DB spectrophotometer equipped with a Beckman linear-log recorder.

The reaction mixture for the stan- dard assay contained the following components; $0.5 \mu$ mole of inosine ; 0.02 unit of xanthine oxidase with $50 \mu$ mole of potassium phosphate buffer ( $\mathrm{pH}$ 7.5) and the enzyme solution to be assayed in a final volume of $1 \mathrm{ml}$ enzyme solution. The mixture of all components except enzyme solution, was preincubated at $37^{\circ}$ for about 1 minute to remove any trace of hypoxanthine or xanthine introduced as a contaminant in the inosine after a preincubation, the reaction was started by the addition of enzyme solution to be assayed. The concentration of formed uric acid was calculated from the reading taking at an A $292 \mathrm{~nm}$ value.

One unit of PNPase was defined as that amount of enzyme which gives an optical density increase of 12.5 per min. ( $1 \mu$ mole of uric acid formation) at 292 nm under above standard assay conditions.

For the assay of substrate specificity, a modification of the Park-Johnson method was employed (1949). The reaction mixture (total volume $0.5 \mathrm{ml}$ ) contained $50 \mathrm{mM}$ Tris- $\mathrm{HCl}$ buffer $(\mathrm{pH}$ 7.8) and $10 \mathrm{mM}$ disodium arsenate for phosphate. The formation of ribose from the purine ribonucleoside (or deoxyribose from the purine deoxyribonucleoside) was determined spectrophotometrically with a sensitive reducing sugar assay method.

\section{Assay of adenosine deaminase}

The activity was measured spectrophotometrically using adenosine as substrate at $\mathrm{pH} 7.5$. In the addition to an excess of nucleoside phosphorylase and xanthine oxidase, the rate of the increase in absorbance at $292 \mathrm{~nm}$, resulting from the conversion of adenosine to uric acid, yields a measure of adenosine desminase activity (Hopkinson and Harris, 1969). The standard assay mix- 
ture contained $0.5 \mathrm{mM}$ adenosine, 0.05 M sodium phosphate buffer ( $\mathrm{pH} 7.5$ ), 0.02 unit of xanthine oxidase, 0.025 unit of nucleoside phosphorylase and $50 \mu \mathrm{l}$ of enzyme solution in a total volume of $1.05 \mathrm{ml}$ were incubated.

\section{Assay of xanthine oxidase}

The absorbance of the reaction mixture at $292 \mathrm{~nm}$ upon the aerobic oxidation of hypoxanthine to uric acid was determined by the method of Kalckar (1947). For the purpose of enzyme assay, $1 \mathrm{M}$ glycine buffer ( $\mathrm{pH} 8.8), 2.58 \mathrm{mM}$ hypoxanthine, and enzyme solution (diluted with $0.07 \%$ bovine albumin solution to make a concentration of enzyme is to be $50-335$ unit) in the final volume of $3.0 \mathrm{ml}$ were incubated for 30 minutes. Incubation mixture was measured spectrophotometrically.

\section{Measurement of protein concentra- tion}

Protein concentrations were measured by the biuret procedure (Gornall et al., 1949) or by the method of Lowry et al. (1951).

\section{Polyacrylamide gel electrophoresis}

The method of Ornstein and Davis (1964) was $\mathrm{r}$ used at $4^{\circ} \mathrm{C}$. Approximately $10 \mu \mathrm{g}$ of the purified PNPase was applied to a $7 \%$ polyacrylamide gel column. The current was regulated at $5 \mathrm{~mA}$. per gel tube. The analytical gels were run in duplicate, with bromphenol blue as an anionic marker. The gels were stained with amidoschwarz black.

\section{Preparation of antibody}

PNPase purified from cow snout epidermis was mixed with an equal volume of Freund's complete adjuvant.
Immunizing injections (500 $\mu \mathrm{g}$ of protein) were made in the foot-pads of guinea pigs. Two weeks later, guinea pigs were given with simple booster injection intraperitoneally with $500 \mu \mathrm{g}$ of the immunogen 2 weeks after initial immunization. One month after the last booster injection, blood was collected. In the separate experiment, calf spleen PNPase (purchased from Böehringer Mannheim) was used as reference.

\section{Ouchterlony double diffusion analysis}

Gel diffussion precipitation was carried out as described by Ouchterlony (1962). The immunodiffusion media containing $1 \%$ agarose, $0.1 \%$ sodium azide, and phosphate buffered saline, was poured on a slide glass to make a depth of $1 \mathrm{~mm}$. Four-millimeter diameter wells were punched with a template resulting in a pattern of wells with center-to-center distances of $8 \mathrm{~mm}$. After filling the wells with the appropriate proteins, the plates were incubated at $37^{\circ}$ for at least 12 hours.

\section{RESULTS}

\section{Enzyme activity in the epidermal homogenate}

Enzyme activity was proportional to the amount of enzyme used (Fig. 1) and to time of incubation (Fig. 2).

Purine nucleoside phosphorylase activity in cow snout epidermal homogenate was assayed with inosine and guanosine as substrate respectively. PNPase activity with inosine as substrate is approximately 2 times higher than that with guanosine as substrate. In this paper, PNPase is particularly to be discussed for inosine as substrate. Table 1 shows the specific activities of 
PNPase and the related enzymes with purine base metabolism in various bovine tissue extracts; liver, kidney, intestinal epithelium and snout epidermis. As compared with other tissues, the snout epidermis contains relatively high activity of enzymes except for xanthine oxidase.

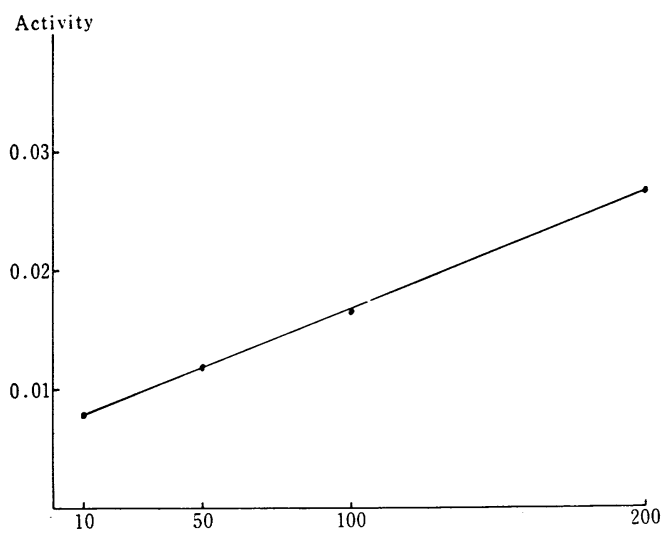

Purified PNPase added $(\mu \mathrm{l})$.

Concentration of protein $(39 \mu \mathrm{g} / \mathrm{m} 10)$

Fig. 1 Effect of enzyme concentration on PNPase activity.
To study the distribution of PNPase activity in relation to depth of epidermis, a guantitative determination was made on successive slices of epidermis. According to the process of epidermal preparation, usually 60 slices $(10 \mu$ thickness) could be obtained with a laboratory cryostat-microtome.

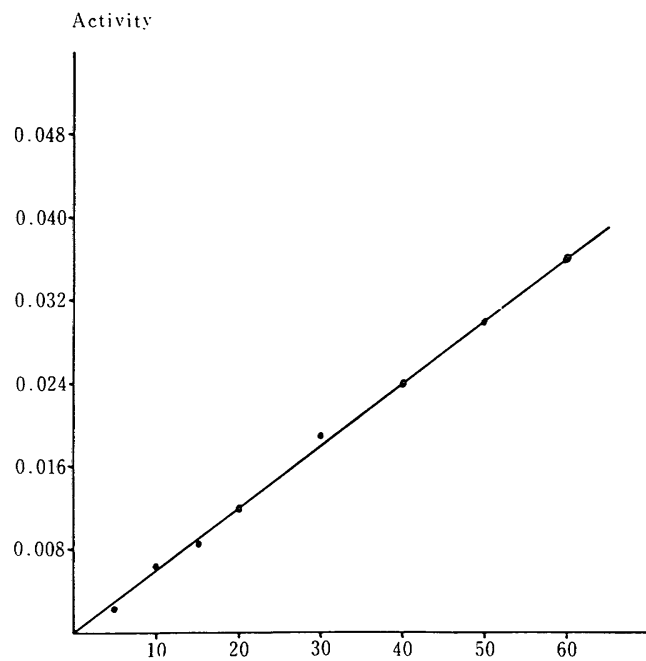

Incubation time (minute)

Fig. 2 Time course of PNPase activity.

TABLE 1

Comparison of purine nucleoside phosphorylase activity in the bovine various tissues

\begin{tabular}{l|c|c|c|c}
\hline & Epidermis & Liver & Kidney & $\begin{array}{c}\text { Intestinal } \\
\text { Epithelium }\end{array}$ \\
\hline $\begin{array}{l}\text { Purine nucleoside } \\
\text { phosphorylase }\left(\times 10^{-3}\right) \\
\text { (with inosine as substrate) }\end{array}$ & $416.2 \pm 21.8(3)$ & $86.4 \pm 4.03(3)$ & $129.7 \pm 8.15(3)$ & $195.1 \pm 7.82(3)$ \\
Adenosine deaminase $\left(\times 10^{-3}\right)$ & $60.8 \pm 5.79(3)$ & $36.1 \pm 2.34(3)$ & $11.5 \pm 1.11(3)$ & $29.4 \pm 0.31(3)$ \\
Xanthine oxidase $\left(\times 10^{-3}\right)$ & $0.110 \pm 0.005(3)$ & $0.441 \pm 0.042(3)$ & $0.084 \pm 0.024(3)$ & $0.079 \pm 0.016(3)$ \\
\hline
\end{tabular}

Enzyme activity: unit per $\mathrm{mg}$ protein

( ) : number of samples determined 
TABLE 2

Distribution of enzyme activity of purine metabolism in succesive layers of cow snoute epidermis

\begin{tabular}{c|c|c|c}
\cline { 2 - 3 } & Upper layer & Middle layer & Lower layer \\
\hline $\begin{array}{c}\text { Purine nucleoside phosphorylase } \\
(\text { with inosine as substrate) }\end{array}$ & $372.1 \pm 66.4(3)$ & $327.1 \pm 3.10(3)$ & $258.3 \pm 19.0(3)$ \\
Adenosine deaminase $\left(\times 10^{-3}\right)$ & $131.2 \pm 3.71(3)$ & $100.1 \pm 6.68(3)$ & $67.7 \pm 1.25(3)$ \\
Xanthine oxidase $\left(\times 10^{-3}\right)$ & $0.139 \pm 0.006(3)$ & $0.131 \pm 0.031(3)$ & $0.131 \pm 0.01(3)$ \\
\hline
\end{tabular}

Enzyme activity: unit per $\mathrm{mg}$ protein

( ) : number of samples determined

The epidermis was divided into three successive layers with about 20 consecutive slices respectively (upper, middle and lower epidermis).

Table 2 shows the distribution of enzyme activity of PNPase, adenosine deaminase and xanthine oxidase in the three successive layers. The specific activities of these enzymes are found to be high in the upper layer of epidermis, except for xanthine oxidase.

\section{Purification of PNPase from cow snout epidermis}

All steps were carried out at $3-5^{\circ}$, unless otherwise stated.

Step 1: Preparation of extract

The epidermis (20 $\mathrm{g}$ wet weight) was homogenized in 10 vol. of distilled water, followed by centrifugation at $20,000 \times \mathrm{g}$ for 15 minutes at $0^{\circ}$. The resulting supernatant could be stored for lengthy periods in a deep freezer without a significant loss of activity.

Step 2: Ammonium sulfate fractionation

The above supernatant solution was brought to $40 \%$ saturation by adding a solid ammonium sulfate $(23.11 \mathrm{~g} / 100 \mathrm{ml}$ of eluate). After the $30 \mathrm{~min}$ in room temperature, the precipitate was removed by centrifugation at $9,000 \times \mathrm{g}$ for $30 \mathrm{~min}$. To the supernatant fluid a solid ammonium sulfate $(12.31 \mathrm{~g} / 100 \mathrm{ml}$ of supernatant fluid) was added to bring the concentration to $60 \%$ saturation. After 60 minutes, the precipitate was collected by centrifugation at $9,000 \times \mathrm{g}$ for $40 \mathrm{~min}$, and dissolved again in 15 $\mathrm{ml}$ of $0.1 \mathrm{M}$ Tris-acetate buffer, $\mathrm{pH} 7.5$ (loss of the total activity was $27.6 \%$ ). The solution obtained from the ammonium sulfate fractionation was dialyzed overnight against several changes of $0.03 \mathrm{M}$ Tris-acetate buffer, $\mathrm{pH} 7.5$.

Step 3: DEAE-cellulose column chromatography

The dialyzed solution was loaded on a DEAE-cellulose column (acetate form, $2.5 \times 12 \mathrm{~cm}$ ) which had been previously equilibrated with $0.03 \mathrm{M}$ Tris-acetate buffer, $\mathrm{pH} 7.5$ Fifty $\mathrm{ml}$ of the same buffer, was used to eluate the first protein peak, and then a linear gradient was produced with Tris-acetate buffer ( $\mathrm{pH}$ 7.5) varing from 0.03 to 0.34 of molar concentration. The eluate was collected in the test-tubes with $10 \mathrm{ml}$ each. The optical density of eluate was read at $280 \mathrm{~nm}$. The result obtained in this procedure is shown in Figure 3. 
The three main protein peaks were obtained, elution of $95 \%$ of the enzyme activity emerged between 60 and 100 of tube number. The fractions demonstrating PNPase activity were pooled, and was hereafter referred to as the

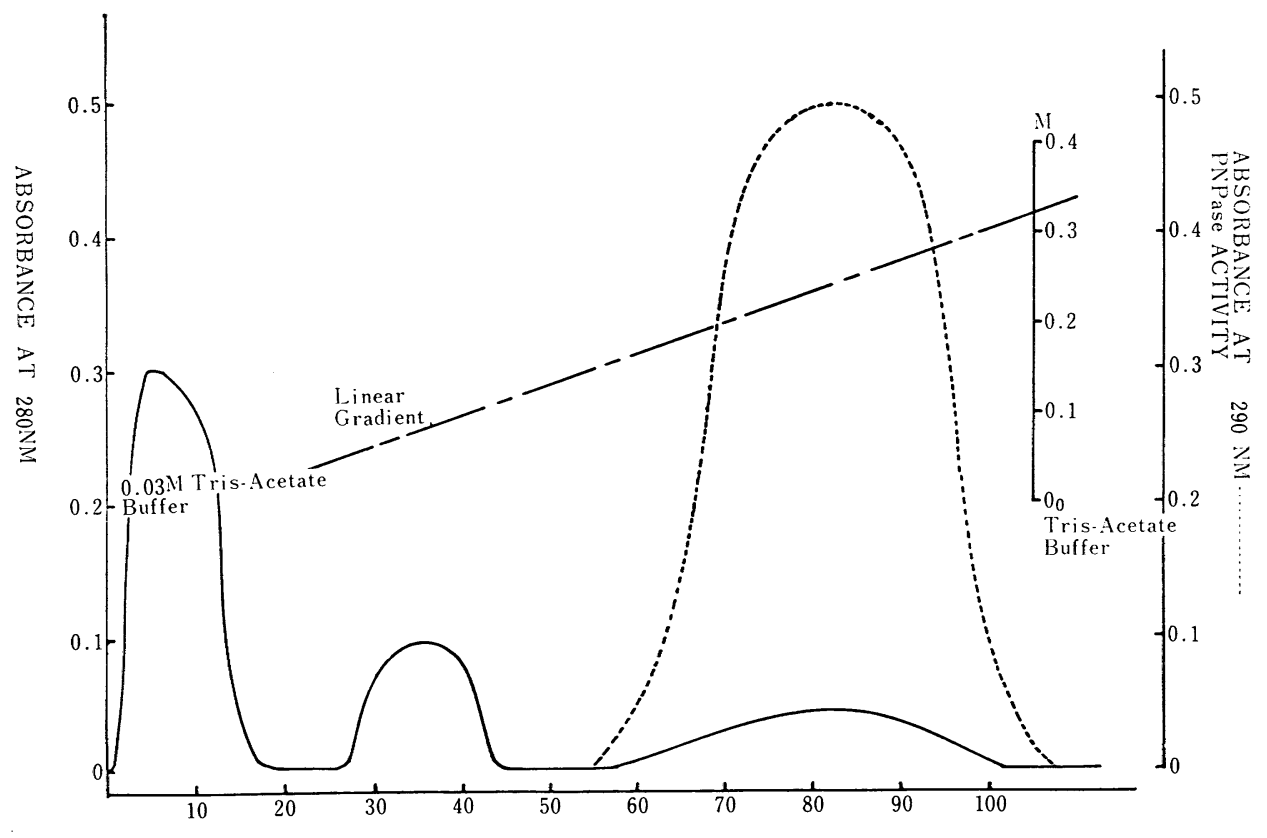

FRACTION NUMBER

Fig. 3 DEAE-cellulose column chromatogram of cow snout epidermal PNPase obtained in step 2 of the purification procedure.

TABLE 3

Purification of purine nucleoside phosphorylase from cow snout epidermis

\begin{tabular}{|c|c|c|c|c|c|c|}
\hline Fraction & $\begin{array}{l}\text { Total } \\
\text { volume } \\
\quad(\mathrm{ml})\end{array}$ & $\begin{array}{l}\text { Total } \\
\text { activity } \\
\text { (units) }\end{array}$ & $\begin{array}{c}\text { Specific } \\
\text { activity } \\
\text { (units/mg) }\end{array}$ & $\begin{array}{l}\text { Protein } \\
(\mathrm{mg} / \mathrm{ml})\end{array}$ & $\begin{array}{c}\text { Recovery } \\
(\%)\end{array}$ & $\begin{array}{l}\text { Purifi- } \\
\text { cation } \\
\text { (-fold) }\end{array}$ \\
\hline 1 Homogenate & 200 & 77 & 0.016 & 23.8 & 100 & 1 \\
\hline $2 \begin{array}{l}20,000 \times \mathrm{g} \\
\text { centrifugation }\end{array}$ & 148 & 76 & 0.130 & 4.1 & 99 & 8 \\
\hline $\begin{array}{l}\text { Ammonium sulfate } \\
3 \text { fractionation } \\
(40 \sim 60 \%)\end{array}$ & 20 & 55 & 0.360 & 7.6 & 71 & 22 \\
\hline $4 \begin{array}{l}\text { DEAE-cellulose } \\
\text { (acetate) column }\end{array}$ & 310 & 46 & 3.809 & 0.039 & 60 & 237 \\
\hline
\end{tabular}


partially purified PNPase in the present paper. The summary of the purification processes is given in Table 3 .

In the preparation of antibody, the resulting material was further concentrated by membrane filter (Amicon ; UM $059 \mathrm{~cm}$ ).

\section{Acrylamide gel electrophoresis of purified PNPase}

The partially purified PNPase was applied on the polyacrylamide gel electrophoresis. The pattern obtained from the enzyme preparation is shown in Fig. 4. Only one band was detected. Enzyme preparation appears to be homogenous in polyacrylamide gel electrophoresis.

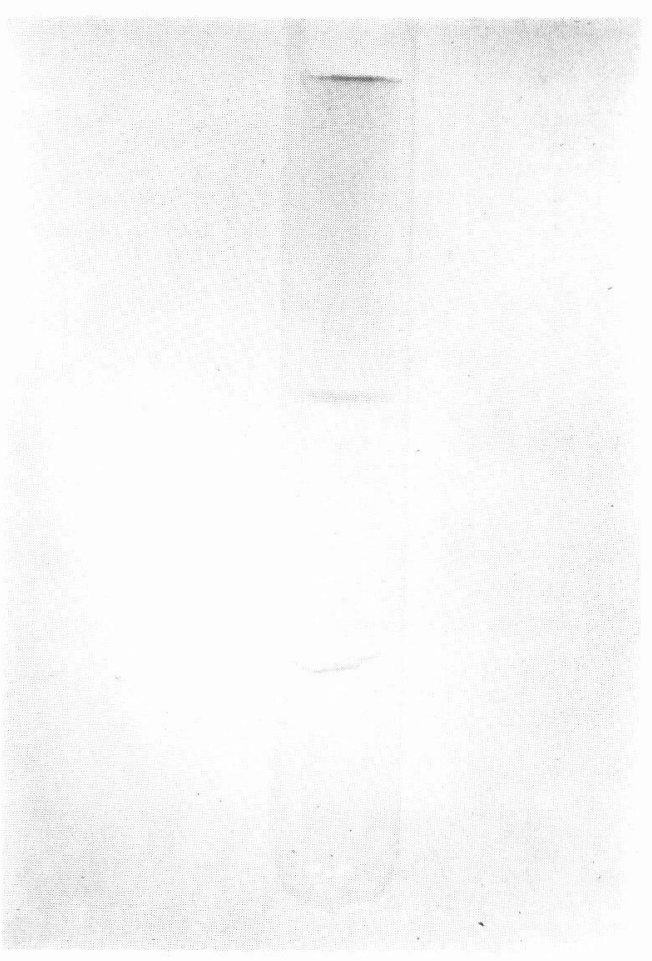

Fig. 4 Polyacrylamide gel electrophoresis of purified PNPase from cow snout epidermis (anode: top and cathode: bottom).

\section{Properties of the enzyme}

pH optimum

The $\mathrm{pH}$ activity curve of the partially purified PNPase is shown in Fig. 5. The $\mathrm{pH}$ optimum was 7.5. (Tris- $\mathrm{KH}_{2} \mathrm{PO}_{4}$ buffer and adjusting to the desired $\mathrm{pH}$ with either $\mathrm{KOH}$ or $\mathrm{HCl}$ ).

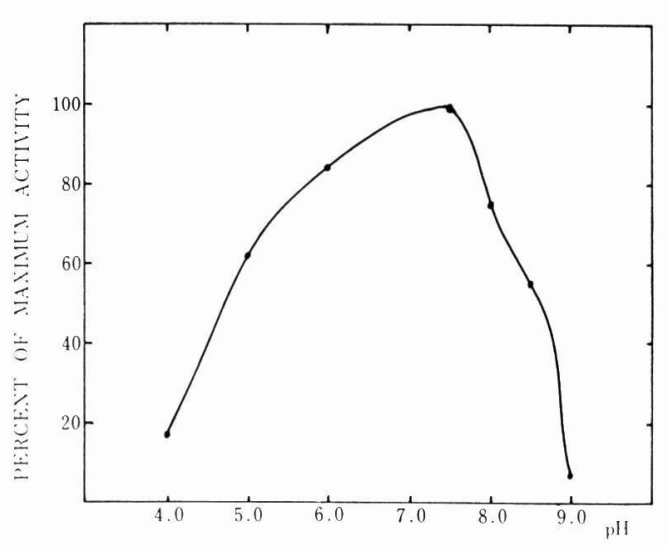

Fig. 5 The effect of $\mathrm{pH}$ on purified enzyme.

Substrate specificity

The enzyme activity of partially purified PNPase was determined by measuring the liberation cf ribose from nucleoside with inosine, guanosine and adenosine as substrate respectively. The substrate specificity was shown in Table 4 as the relative activity for inosine as substrate. Cow snout PNPase scatalyzed inosine and guanosine to the purine base, but dces not react with adenosine. The $\mathrm{Km}$ value for inosine was estimated to be $0.04 \mathrm{mM}$, based on the method of LineweaverBurk plot (Fig. 6). 


\section{TABLE 4}

Comparison of substrate specificity of PNPase from cow snout epidermis. Enzyme activity was measured by determining the amount of reducing sugar formed from the arsenolysis of each substrate in $10 \mathrm{~min}$. Inosine arsenolysis was assigned as value of 100 ; other substrate activities were given as a relative value that of inosine

\begin{tabular}{l|c}
\hline Substrate & Relative activity \\
\hline Inosine & $100 \%$ \\
Guanosine & 45 \\
Adenosine & 0 \\
\hline
\end{tabular}

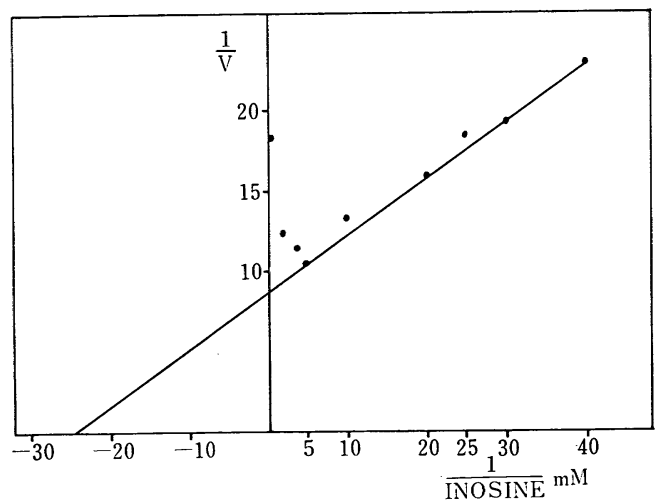

Fig. 6 The effect of concentration of inosine on the velocity of PNPase activity.

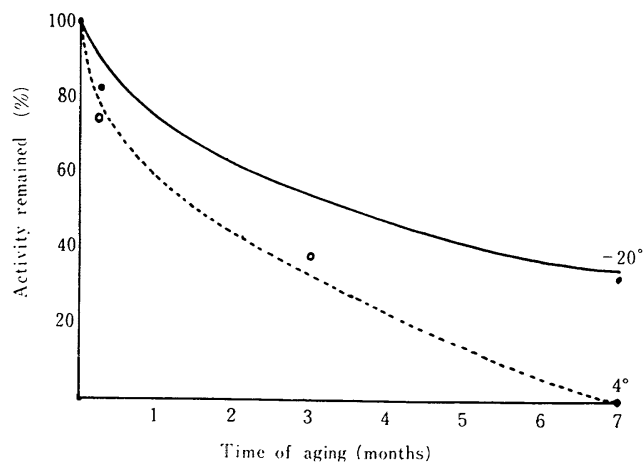

Fig. 7 Effect of aging for 3 months on the enzyme activity of partially purified PNPase.
Effects of p-chloromercuribenzoate

The partially purified PNPase was incubated for 30 minutes at $37^{\circ}$ with various concentrations of $\mathrm{p}$-chloromercuribenzoate (PCMB). As shown in Table 5, PNPase was inhibited by PCMB in high concentration of $10^{-2} \mathrm{M}$ in a final concentration.

\section{Effect of metals}

No significant effect of the $\mathrm{Mg}^{2+}$ or EDTA to the enzyme activity was detected (Table 6).

\section{Stability of enzyme}

The purified enzyme could be stored as a suspension in $80 \%$ saturated ammonium sulfate at $0^{\circ}$ without a significant loss of activity. As shown in Fig. 7, 33\% of the original activity was

\section{TABLE 5}

Effect of $p$-chloromercuribenzoate on the activity of Partially purified PNPase

\begin{tabular}{c|c}
\hline p-chloromercuribenzpate & Enzyme activity \\
\hline $\mathrm{M}$ & $\%$ \\
$10^{-2}$ & 56 \\
$10^{-1}$ & 100 \\
none & 100 \\
\hline
\end{tabular}

TABLE 6

Effect of metals on the activity of partially purified PNPase

\begin{tabular}{rl|c}
\hline \multicolumn{2}{c|}{ Metals } & $\begin{array}{c}\text { Enzyme activity } \\
\text { (unit) }\end{array}$ \\
\hline \multicolumn{2}{c}{ None } & $416.2 \pm 21.8$ \\
\hline $0.1 \mathrm{mM}$ & $\mathrm{Mg}^{2+}$ & 416.2 \\
$1 \mathrm{mM}$ & $\mathrm{Mg}^{2+}$ & 422.5 \\
$10 \mathrm{mM}$ & $\mathrm{Mg}^{2+}$ & 407.9 \\
\hline $0.1 \mathrm{mM}$ & EDTA & 427.8 \\
$1 \mathrm{mM}$ & EDTA & 439.8 \\
$10 \mathrm{mM}$ & EDTA & 438.1 \\
\hline
\end{tabular}


lost by allowing the partially purified enzyme to stand in $0.1 \mathrm{M}$ Tris-acetate buffer ( $\mathrm{pH}$ 7.5) for 3 months at $-20^{\circ} \mathrm{C}$, whereas at $4^{\circ} \mathrm{C}$ more than $55 \%$ loss of activity was found.

\section{Effect of temperature}

The effect of temperature on the partially purified PNPase is shown in Fig. 8. The activity of enzyme was found to have a broad optimum between $30^{\circ}$ and $50^{\circ}\left(40^{\circ}\right)$. The enzyme shows a significant loss of activity above $50^{\circ} \mathrm{C}$.

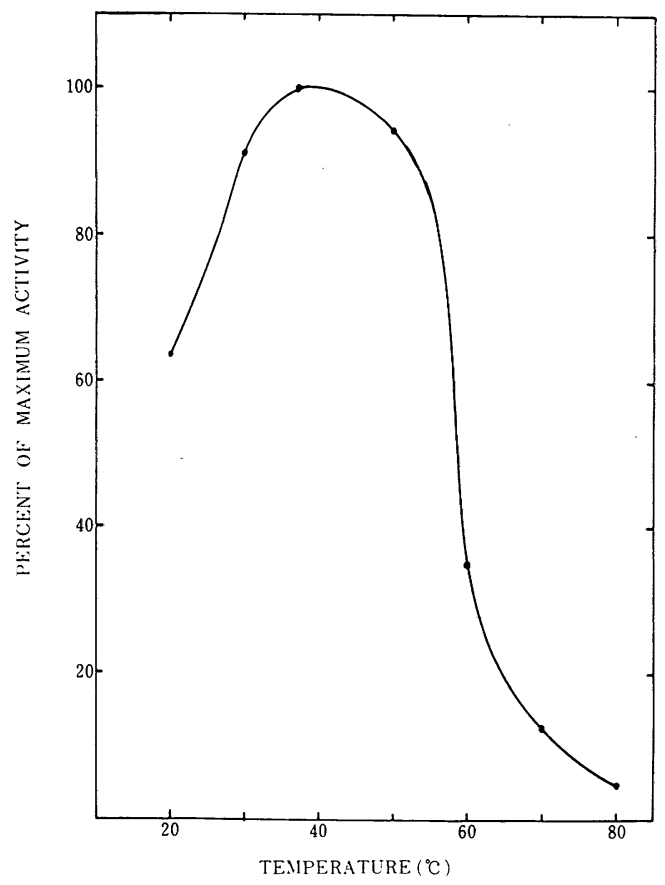

Fig. 8 Effect of temperature on the PNPase activity.

\section{Estimation of molecular weight}

The estimation of the molecular weight was performed according to the

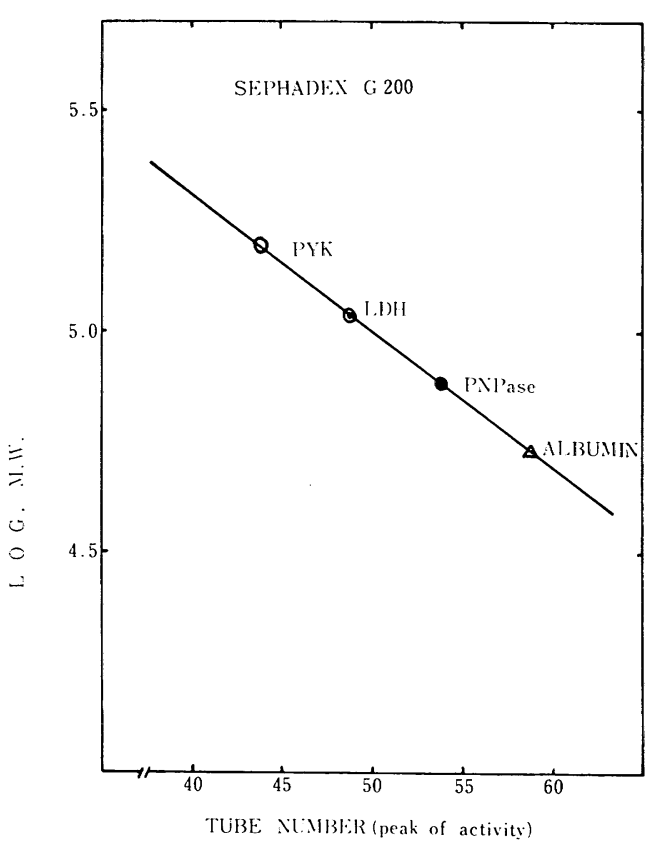

Fig. 9 Estimation of molecular weight of cow snout epidermal PNPase.

method of Andrews (1964) with a sephadex G-200 column $(1.9 \times 50 \mathrm{~cm})$ equilibrated with a $0.1 \mathrm{M}$ Tris-acetate buffer ( $\mathrm{pH}$ 8.0) containing $1 \times 10^{-4} \mathrm{M}$ dithiothreitol. The following marker proteins were mixed with partially purified PNPase in $1.5 \mathrm{ml}$ of $0.1 \mathrm{M}$.

Tris-acetate ( $\mathrm{pH} 7.5$ ) containing $10^{-3}$ M dithiothreitol, pyruvate kinase (PYK ; mol wt 230,000); lactate dehydrogenase (LDH ; mol wt 120,000) and bovine serum albumin (mol wt 67,000 ).

The mixed samples were fractionated by a sephadex G-200 column. The fraction tube numbers showing the highest absorbance at $280 \mathrm{~m} \mu$ in the each separated protein were plotted against the logarithm of the known molecular weights of the proteins. The molecular weight of the cow snout epidermal PNPase was estimated at about 80,000 (Fig. 9). 


\section{Immunologic properties}

Gunia pig antiserum to purified enzyme was tested by the Ouchterlony double immunodiffusion technique (1962) against the purified PNPase from cow snout epidermis and the calf spleen PNPase purchased from Boehringer
Mannheim. An identical single precipitin band was obtained in all of the preparations. The guinea pig antiserum to PNPase prepared from cow snout epidermis and from calf spleen was used to identify with cow snout epidermis, spleen, liver, kidney and intestinal epithelial homogenate.
A
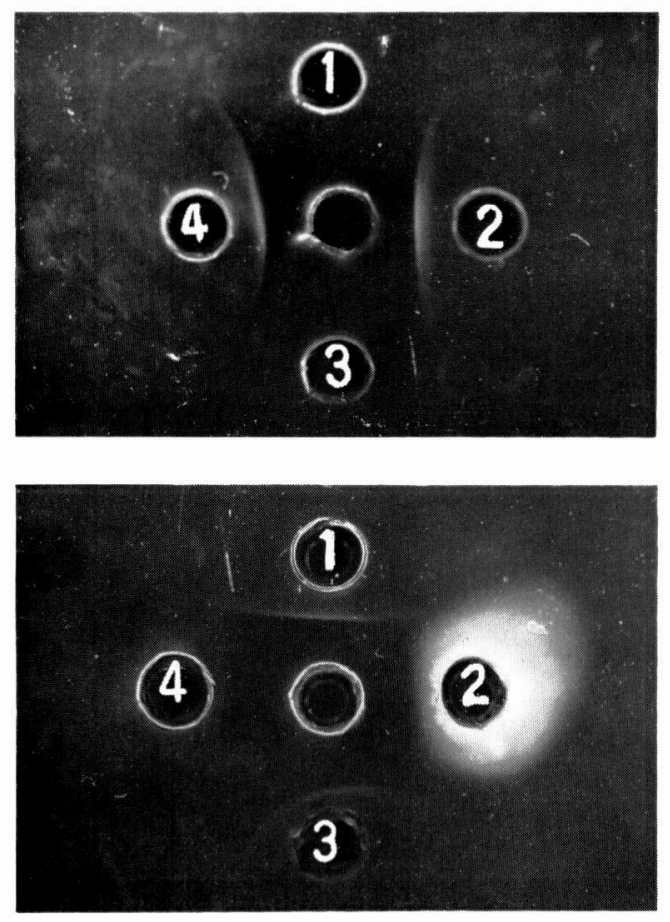

C
B
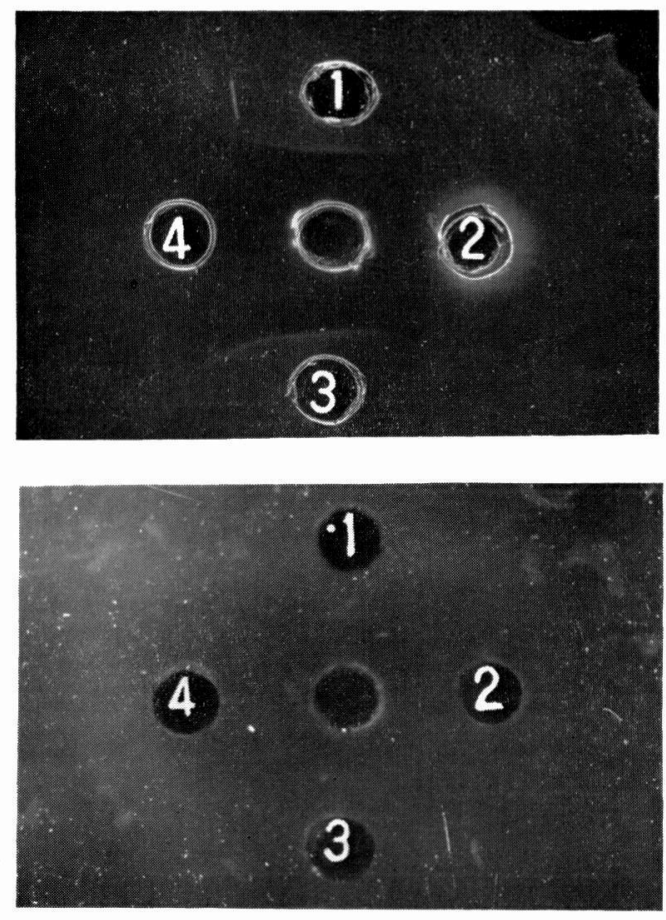

D

Fig. 10 Photograph of immunodiffusion plates.

All wells were filled with $20 \mu \mathrm{l}$ of the indicated protein preparations.

A : the center well contained cow snout epidermal PNPase antiserum. wells 1 and 3 contained calf spleen PNPase, wells 2 and 4 contained cow snout epidermal PNPase.

B : the center well contained cow snout epidermal PNPase antiserum. wells 1 and 3 contained cow snout epidermal PNPase, well 2 contained crude extracts of cow intestinal epithelium, well 4 contained calf spleen PNPase.

$\mathrm{C}$ : the center well contained cow snout epidermal PNPase antiserum. wells 1 and 3 contained cow snout epidermal PNPase, and well 2 contained crude extracts of cow liver, well 4 contained crude extracts of cow kidney.

D : the center well contained calf spleen PNPase antiserum. wells 1 and 3 contained calf spleen PNPase and wells 2 and 4 contained cow snout epidermal PNPase. 
As shown in Fig. $8 \mathrm{~A}, \mathrm{~B}, \mathrm{C}$, the antiserum to cow snout epidermal PNPase cause a precipitation with cow snout epidermal PNPase, but did not precipitate with liver, kidney, intestinal epithelial extract and calf spleen PNPase.

The antiserum to calf spleen PNPase cause a cross-react with calf spleen PNPase, but does not react with others (Fig. 10).

An attempt was made to find the influence of antiserum on the activity of cow snout epidermal PNPase.

The purified PNPase was incubated with $100 \mu \mathrm{l}$ of antiserum for $15 \mathrm{~min}$. at $37^{\circ}$. There was an elevation of $48 \%$ in PNPase activity after incubation.

\section{DISCUSSION}

Levene et al. (1911) early studied the enzymatic degradation of purine nucleosides. In 1945, Kalckar made the important discovery, in which ribose 1-phosphate was found to be one of the products of the PNPase reaction. PNPase was found to catalyze purine nucleotide to purine base and ribose phosphate by transphosphorylation as follows.

purine ribonucleoside $+\mathrm{Pi} \rightleftharpoons$ purine base + ribose 1-phosphate

PNPase is known to catalyze guanosine to guanine, not to convert adenosine to free purine base. Adenosin is deaminated to inosine by adenosine deaminase, and finally, guanine and hypoxanthine are oxidized to uric acid by xanthine oxidase.

In human skin, the presence of PNPase has been demonstrated by Hershey and Mendell (1954). Then, the further metabolism of the purine nucleoside in the epidermis was established to proceed according to the enzymes similar to those described in the other tissues.

In the present work PNPase was purified by ammonium sulfate fractionation and DEAE-cellulose chromatography.

Result of acrylamide gel electrophoresis indicated homogenous preparations. Yield of enzyme was $60 \%$ after 237-fold purification. As compared with other tissues, the snout epidermis was found to contain relatively high activity of PNPase.

PNPase in the epidermis appears to play an important role in the metabolism of nucleic acid. Uric acid has been known to be a final product of purine base in the mammalian tissue. Although an almost complete degradation of nucleoprotein occurs in the horney layer, the presence of uric acid has not been found at all in human epidermis (De Bersaqves, 1967 ; Schwarz, 1963).

Cow snout epidermal PNPase activity was also highest in the upper layer. The unique location of PNPase activity suggests that the enzyme may play a role in the latter stages of keratinization.

In the present work, xanthine oxidase exhibit a low activity in cow snout epidermis. It is interesting that PNPase related with a production of purine base is found high in activity. However, the present study can not dissolve the problem how PNPase plays a biological role in connection with uric acid metabolism in the epidermis. Concerning the distribution of enzymes of cow snout epidermis, the data reported by Mier et al. (1976) showed that acid phosphatase was found mainly in the upper keratinizing zone. In our laboratory, the extremely high activity of nuclease was found in the upper layer (Ogura et al., 1977 ; Hidaka, 1976 ; Miyagawa and Ogura, 1971). In the present paper, PNPase was also high in the upper layer of cow snout epidermis. 
As shown in the results of Ouchterlony (Fig. 10), the enzyme protein of PNPase is immunologically different from that of liver, intestinal epithelium, kidney and spleen. The findings in the present paper suggest that PNPase in the epidermis shows an organ specificity.

\section{ACKNOWLEDGEMENTS}

The author wishes to express appreciation to Dr. Prof. R. Ogura, in the Department of Medical Biochemistry for his helpful guidance and support concerning performance of this research, and to Dr. Prof. M. Shingu in the Department of Virology for his excellent support with immunological study. The auther is grateful to Dr. Prof. F. Yamashita in the Department of Pediatrics for encouragement.

The stimulating discussion with $\mathrm{Dr}$. T. Hidaka, Instructor in the Department of Medical Biochemistry are gratefully acknowledged.

\section{REFERENCES}

ANDREws, P. (1964). Estimation of the molecular weights of proteins by Sephadex gelfiltration. Biochem. J., 91, 222-233.

De Bersaques, J. (1967). Purine and pyrimidime metabolism in human epidermis. J. Invest. Derm., 48, 169-173.

Gornall, A.G., Bardwill, C.J. and David, M. M. (1949). Determination of serum proteins by means of the biuret reaction. J. Biol. Chem., 177, 751-766.

Hershey, F. B. and Mendle, B. J. (1954). Quantitative histochemistry of burned and normal skin. Surgical Forum, 5, 745-749.

HidasA, T. (197j). Purification and characterization of acid phosphatases from cow snout epidermis. J. Kururne Med. Assoc., 39, 34-53.
Hopkinson, D. A. and Harris, H. (1969). Further data on the adenosine deaminase (ADA) polymorphism and a report of a new phenotype. Ann. Hum. Genet, 32, 361-367.

KALCKAR, H. M. (1945). Enzymatic synthesis of nucleosides. Federation preceedings, 2, 248-252.

KALCKAR, H. M. (1947). Differential spectrophotometry of purine compounds by means of specific enzymes. 1. determination of hydroxypurine compounds. J. Biol. Chem., $167,429-443$.

Levene, P. A. and Medigreceanu, F. (1911). On nucleases. J. Biol. Chem., 9, 65-83.

Lowry, O. H., Rosebrough, N. J., Farr, A. L. and RANDAll, R. J. (1951). Protein measurement with Folin phenol reagent. J. Biol. Chem., 193, 256-257.

Mier,P.D., Cotton,P.W.K., Van Den Hure, J. and JonclRheER VANNeste, M. M. H. (1976). Lysosomal hydrolases of the epidermis. Brit. J. Dermatol, 94, 535-538.

Miyagawa, T. and Ogura, R. (1971). The Biochemical property and physiologic significance of deoxyribonuclease in the epidermis. J. Invest. Derm., 57, 330-336.

Ogura, R., Koga, H. and Hidaka, T. (1977). Biochemical studies on nucleases in relation to epidermal DNA catabolism. "Biochemistry of cutaneous epidermal differentiation." (Ed. by M. Seiji and I. A. Bernstein) pp. 127-147, University of Tokyo Press, Tokyo.

Ornstein, L. and Davis, B. J. (1964). Disc electrophoresis. Ann. N. Y. Acad. Sci, 121, 321-349.

Ouchterlony, O. (1962). Diffusion-in-gel methods for immunological analysis. Progr. Allerg., 6, 30-154.

PARK, J.T. and Johnson, M. J. (1949). A submicrodetermination of glucose. J. Biol. Chem., 181, 149-151.

ŠHwarz, E. (1963). Untersuchungen zum Schicksal der aus Nucleinsaüren beim Zellabbau während der Epidermalen Keratinisation freiwerdenden purine. Archiv. für Klinische $u$. experimentelle Dermatologie., 216, 427-445. 